\title{
22. シネ撮影系における視営用チャートの作成
}

（シネフィルム像への応用）

Frame for visual chart on the Cine Radiography (The application to Cineradiography)

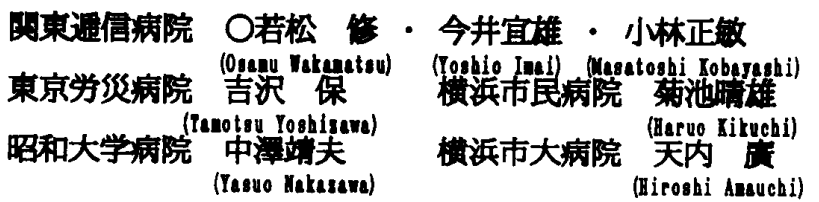

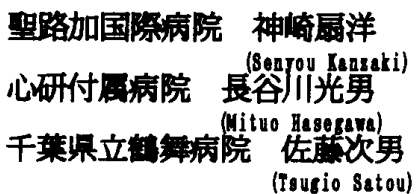

（目 的） シネ提影研究会視賞検行班ては、これまでCRTの設定条件、シネブロシェクタの特性評価

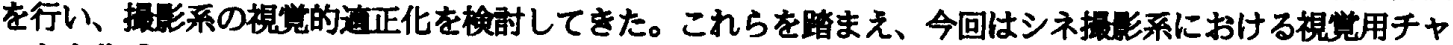
一トを作成し、シネフィルム像の視党的評価に応用てきるか検即したので報告する。

（使用装是およひ器具）

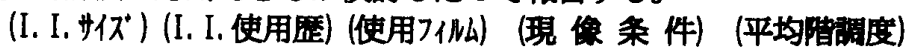

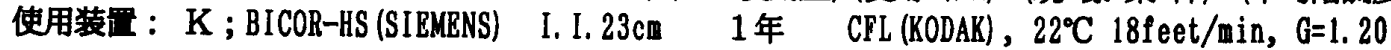

$R$; ANGIOSKOP (SIRMENS) I. I. $27 \mathrm{~cm} \quad 2$ 年 CFJ (KODAK), $26^{\circ} \mathrm{C} 19 \mathrm{feet} / \mathrm{min}, G=1.40$

$\mathrm{S} ; \mathrm{BICOR}$ (SIRMENS) $\quad$ I. I. $27 \mathrm{~cm} \quad 6.5$ 年 $\quad$ CFJ (KODAK), $26^{\circ} \mathrm{C} 30 \mathrm{feet} / \mathrm{min}, \mathrm{G}=1.45$

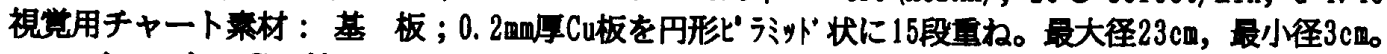

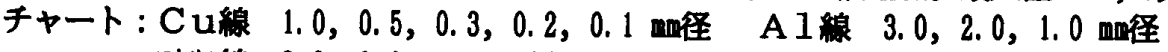

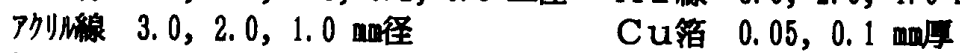

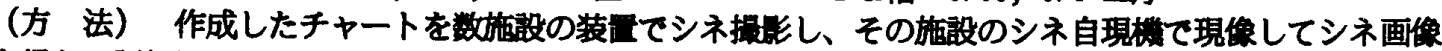

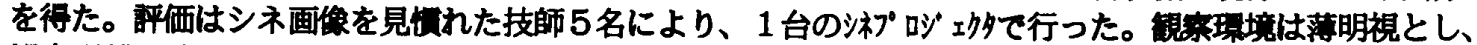

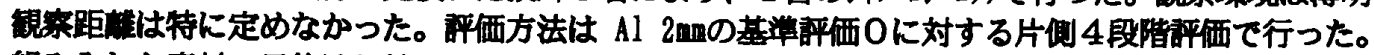

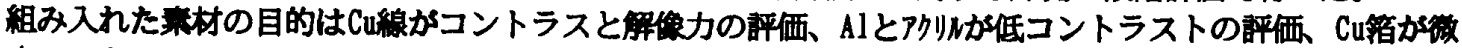
少コントラストの評価である。シネ画像にはチャート全てが入らないので 6段目より内側のみで評価した。

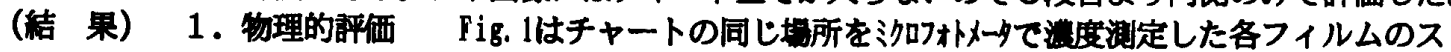

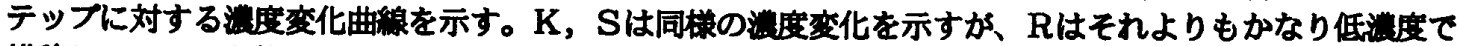

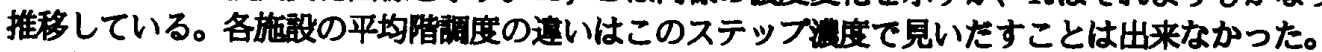

2. 視賞的評価 ここではある特定の評洒のみについて述べるFig. 2は8段目CU線の評価を示す。Kの 評価が高く、R，Sはそれより変化しており、I. I. の使用歴の長い施設ほと評価は低い。Fig. 3はCu線の長

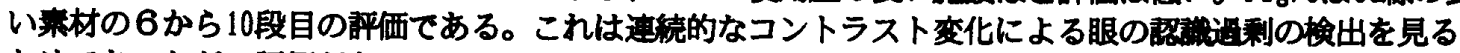
ためてあったが、評価が各ステップことてはなく、それそれ5段をトータルした評価でっったため、平均 的な評価の值しか表れず、短い等材と同等に評価されていた。Al線も同粎の結果てあった。各ステップ

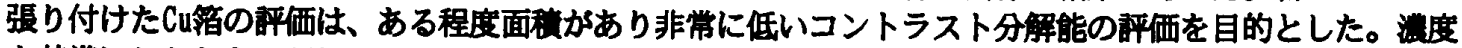

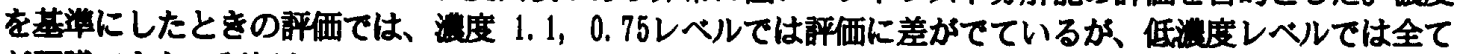
が琶傤てきない枰価を示している。

（結 論） われわれはこれまてに種々のチャートや方法の蛽いによる、視賞的な画像評価を行ってきた。 今回もその一鿓てあり、実殹前には今まてに示したデータり評価か狭い管囲て推移するものと考えてい たか、結果は逆に評価が開く方向で推移した。これらを続合的に判断すると、作成したチャートは視賞的 評価に通しているものと考える。また、作成費用も安価で済み、シネ撮影システム系全般での管理にも応 用でることて、さらに有用性があるものと考える。今後、われわれはシネ提影システム、特に今回報告

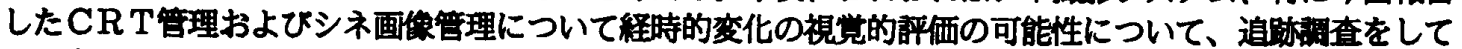
いく考えている。
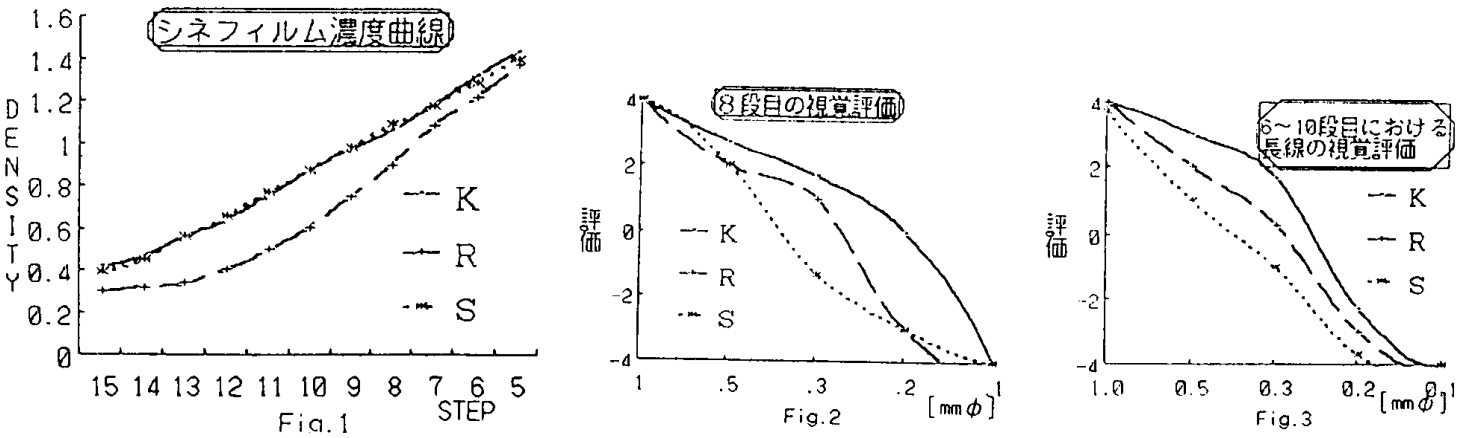